\title{
Using storytelling with adult EFL learners: an enriching classroom experience
}

\begin{abstract}
'Teachers' first role is to create an atmosphere in which stories are valued in human terms much more than in 'learning English' terms. Then, students should reveal in their stories and let them see it'.
\end{abstract}

Adriana M. Vecino

Andrew Wright

\begin{abstract}
Storytelling has obvious benefits in the development of speaking and listening skills, vocabulary and memory abilities. It also nurtures reading and writing skills and offers learners opportunities to increase their confidence. Given the great value in employing storytelling as a support when learning a foreign language, I decided to use this technique with one of my adult EFL classrooms and observe the benefits and possible constraints. This paper presents the theoretical foundations that underlie my pedagogical innovation as well as the results obtained from its implementation. In addition, valuable reflections invite teachers to integrate storytelling into their English lessons and explore their use with adult learners.
\end{abstract}

Keywords: storytelling, benefits, language skills, adult EFL learners.

\section{Resumen}

El uso de narración de historias tiene beneficios obvios en el desarrollo de la producción y la comprensión oral, y en el enriquecimiento del vocabulario y la memoria. Asimismo, mejora las habilidades de lectura y escritura y ofrece a los alumnos la oportunidad de incrementar su confianza. Dado el gran valor de emplear la narración de historias para apoyar el aprendizaje de una lengua extranjera, decidí utilizar esta técnica con uno de mis grupos de estudiantes de Inglés como lengua extranjera y observar los beneficios y posibles limitaciones. En este documento presento el marco teórico que respalda mi innovación pedagógica, así como los resultados obtenidos después de su implementación. Además, presento unas reflexiones valiosas que invitan a los profesores a integrar la narración de historias en sus clases de Inglés y explorar su uso con adultos.

Palabras claves: narración de historias, beneficios, habilidades de la lengua, estudiantes adultos de Inglés como lengua extranjera.

* Received:17-07-06 / Accepted: 05-09-06 


\section{Introduction}

As language teachers, we have, at some time, asked our students to read a story as homework and then complete the exercises provided at the back of the book or write a summary. Even though the results of such activities might have been quite successful, the use of stories in the classroom could certainly go beyond than filling out activity sheets.

There are many reasons why we should use stories in our English classes. According to Deacon \& Murphey (2001) "stories provide students with opportunities to listen to language in context rather than in bits and pieces" (p. 10). Students interact actively with the language in the stories. They listen to the sounds of the words, visualize them, and play with them. They grasp the meaning of entire words at a time and, further, they can use them to communicate ideas. This process facilitates the learning of words and expressions in the new language and leads to fluency.

Equally important, stories allow students to pass on accumulated wisdom, beliefs, and values. They offer profound insights into human nature, the cosmos, and spirituality. They capture all sorts of truths about life and death. They are like a fountain from which students can quench their thirst for knowledge.

In addition, stories help students to develop critical thinking skills as they reflect upon the issues raised in the text and examine their own perceptions in regard to them. Teachers can assign activities that require student's creative, original thinking. Thus, students are required to relate their own thoughts and positions and cannot merely repeat what the teacher has said.

Stories also have the power to reach deep within students' sensitive areas that regular teaching may not visit. When telling and discussing stories, students reveal their personality traits, beliefs, and feelings; they also develop awareness of the needs and emotions not only of the characters but also of others. Moreover, stories help students to talk, think, and laugh about the wondrous and mysterious details of this thing we call life. And, it is precisely this deep impact stories cause that can make language learning an enriching experience that students find intrinsically valuable.

\section{Rationale}

Given all the benefits of using storytelling in the language classroom, I decided to implement this technique as a means to enhance my students' language 
skills in English and foster their love for this exciting and enchanting form of entertainment and learning. Even though storytelling has been widely used with young learners of English, its utilization with adults has not been explored much. Many of us have not provided an avenue for all of our students to remember the sustaining value of literature. We have forgotten that as literature probably contains the widest variety of syntax and the richest variations of vocabulary, it is definitely a good way to encourage students' comprehension and fluency in the target language. Because students encounter in storybooks nearly every kind of communicative technique speakers use, they can learn to communicate their ideas and thoughts more effectively. Moreover, as they immerse in the wonderful world of a story, they become part of it and bring life to its characters and events with their valuable comments and reflections. Thus, they become active listeners who, at the same time, can learn to weave a story that reels others in.

From my perspective, implementing storytelling with my adult EFL students was a challenge as I wanted to discover their reactions when approaching the reading of the storybooks in a different way from which they were used to. Hence, I expected to gain knowledge regarding not only their language skills performance but also their feelings and attitudes towards the literature itself. I was hoping to find a very positive response but I knew there might be negative ones too. However, I had a strong desire for doing more than asking my students to read a book to learn and practice the past simple of English verbs, and I was ready to face whatever reaction they might have.

Furthermore, I was eager to see the results of my pedagogical intervention and share the insights with my colleagues and the academic director of the institution where I currently work. Thus, I expected that showing them the benefits and possible constraints of using storytelling in our adult English courses would allow us to construct a better picture of what we could obtain from them, especially in terms of their language skills and interaction with literature. They could also feel encouraged to integrate stories in their lessons and start perceiving literature as an invaluable pedagogical tool.

\section{Literature Review}

The interest in this review is to explore some of the literature written on storytelling in pedagogy, especially as it relates to second language education. 
The focus will be on what proponents claim as the specific instructional outcomes when using storytelling, as well as theoretical underpinnings to suggest storytelling as an effective tool for language instruction. In the first part of the review, I present some arguments in favor of storytelling. Next, I describe some of the benefits of using storytelling in language classrooms. Then, I state the criteria for selecting the story and mention the storytelling performance skills we need to take into consideration. Finally, I suggest some activities teachers can do to implement storytelling as an enriching experience in the classroom.

\section{In support of storytelling}

Nothing captures our attention quite like a good story. Long before there was television, movies, radio, and even books, people told stories as a way to entertain and educate.

Today, the art of storytelling continues as we tell stories to children before they go to bed, make up excuses for being late, share secrets or gossip, and talk about an incident at work with a colleague. Telling stories is in our human blood. We all love telling others about what happens in our hectic days and enjoy learning through tales of their sufferings and triumphs. Each day, we are unconsciously creating the plot, characters, climax and resolution of our life stories.

But, this art of sharing a story or experience with others can definitely be transported into our language classroom. Our students, young or old, need stories. They need to communicate who they are, where they come from, what they have experienced and what they expect. Then, our role as educators should be guiding students in the discovery and creation of stories in which they can reveal their social human nature.

\section{Stories in classrooms}

There are numerous arguments that favor the use of storytelling in the language classroom. Morgan and Rinvolucri (1983) discuss teacher use of stories as an effective way to create listening comprehension activities and written comprehension questions. We can make questions about the events in the story, the places the characters visited, or their reactions to a specific 
situation. When we ask students to retell the story, they make an effort to recall details and sequence, which enhance both their listening and speaking skills. Besides, stories provide students with an opportunity to practice and learn new grammatical and lexical structures when being asked to answer these comprehension questions.

In addition, Morgan and Rinvolucri (1983) argue that, as stories are told, affective filters are lowered and language acquisition takes place more naturally. As students enjoy listening to the story, telling it, and doing the follow-up activities, the anxiety and pressure they sometimes experience during other class activities could be overcome. They feel truly encouraged to state their opinions and use their foreign language without restrictions. Thus, as Berman (2006) points out, storytelling "can heighten their ability to communicate thoughts and feelings in articulate, lucid manner" (p.1).

Moreover, Pedersen (1995) claims that stories convey literary and cultural heritage. These pieces of literature students have contact with offer them a rich source of beliefs, traditions, and values that connect them with their humanness. They also lead them to understand how their past has influenced their present. All the personal recollections of past events, personal memories, and vivid, imaginative accounts of the events of their lives are shared in storytelling. Students learn to share their stories while learning to appreciate stories from others.

Furthermore, storytelling encourages students' creative writing. As Hughes and Hughes (1999) state, storytelling linked with writing projects can be used to engage learners in the sharing of personal narratives, cultural experiences, and folktales" (p. 27). Storytelling incites students to open their imagination, envision another place, encompass another world, and experience another life and time. It allows them to use the power of words to become the narrators of their fictitious world.

\section{When selecting the stories}

Story selection is critical because not all books can be equally effective with learners. According to Hughes and Hughes (1999), the story's content and language should be appropriate to the student's age and intellectual level. However, as they mention, the level of difficulty should be "within the student's grasp, yet a bit challenging" (p. 27). It is also important to choose a story 
that presents problematic situations students can reflect upon and cultural issues they can exchange views on. Also, we should pick a story that makes students interested and curious about how it is going to end and which seems to flow into our speaking voice. Besides, stories should contain illustrations that help teachers explain new vocabulary and capture the audience attention (Smallwood, 2003).

\section{Effective Storytelling Performance Skills}

Good storytellers lead the audience along the path of the story. They do it confidentially and clearly through voice, words and body. So, what do teachers and students need to become good storytellers? There are definitely some traits they have to demonstrate to make story-telling an enjoyable and significant experience. In his manual for beginners, McWilliams (1998) presents the most important oral storytelling skills we should take into account. First, he advises to deliver the story with sincerity, enthusiasm and animation. He also recommends speaking with an appropriate volume, employing clear enunciation, using non-monotonous, vocal expression and differentiating our natural voice from character voices to make them believable. Moreover, storytellers should also make eye contact with the audience, use appropriate and natural gestures and facial expressions to clarify the meaning of the text and effectively present the sequence of events to keep listeners' interest throughout. In order to involve the audience more, he suggests asking participants to make sound effects or sing chants. Having a distinct change in our pace, voice, or mood, and creating an unexpected twist in the narration are considered good attention keepers too.

And, the best way for teachers to improve these skills is to practice telling stories. We should strive not only for teaching new language but also for transporting students to the imaginary world created for them. In this way, teachers' words should be inspiring and very descriptive to make vivid pictures of the story events and characters.

\section{Ways of using stories in class}

There are many different ideas for integrating the story into the lesson. However, the most practical way of preparing activities and materials related to the story is to think of: before, during and after. The following suggested activities, which have been taken and adapted from Pedersen's (1995) article Storytelling 
and the Art of Teaching, Berman's article (2006) Ways of using stories in an ELT classroom and my own teaching experience, give further practice of the language that is presented in the story and develop it more. Educators can use these story-related activities to give students a chance to play with their imagination, practice motor skills, and develop the different language skills of reading, writing, listening, speaking and also very importantly thinking.

\section{Before}

- Learn the story as a whole rather than in fragments. Don't try to memorize it. Outlining the story is a good way to learn its sequence of events and characters.

- Practice telling the story to another person and receive feedback. You can also tape record it, have a listen, and make changes accordingly.

- Do some little research beforehand about the main topic of the story.

- Use an overhead projector, audio or video recording, shadow theater, masks, puppets, make up, etc., to perform stories in a more creative and fun way.

- Get the students sitting on the floor or in a circle of chairs in front of you, so they are all focussed on the story and so they can all see the pictures.

- Pre-teach or revise vocabulary related to the story using flashcards.

- Have a brainstorming session to find out how much the class already knows about the topic of the story. Pin a visual up on the whiteboard and invite the learners to write associated vocabulary around the picture.

- Use the book's cover to make predictions about the story.

During

- In every picture/page elicit any vocabulary they may know. 'What can you see?' 'What animal is this?' etc. Students may respond in their L1 and teacher can repeat the word back in English, so they all hear it and can link it to the meaning.

- Read the dialogue/narration as it appears on the page with exaggerated intonation, repeating if necessary. 
- Vary voice inflection and tone along with body movement and eye contact to keep momentum and audience focus.

- Ask a few simple questions about the story. 'Is the tall man happy?' 'Are they going to tell the secret?' 'Where are they?' etc. This encourages interaction and makes students think more consciously about the story.

- Use props to make sound effects or represent characters.

- Before moving on to the next page encourage the students to guess what will happen next. Prediction is natural when following a story and also encourages imagination as well as language use.

- Evaluate the audience reaction continuously, and increase or decrease involvement depending on the need to stimulate or calm the students for better story effectiveness.

After

- Have each of the students take the part of one of the characters and re-tell the story from his/her point of view. The re-telling can be written or spoken.

- Invite students to write a letter to one of the characters in the story-asking for advice, praising or criticizing the character.

- Cut up the story into paragraphs and have students work cooperatively to re-order them.

- Show students how to make, write and illustrate a book, which is then exhibited in the classroom or in a web page. It is important to make them feel comfortable about their productions and praise them for their effort.

- Students can draw a picture of their favorite part of the story, share with the class and explain why they like it.

- They can also make a collage or poster using vocabulary learned in the story. Their works can be exhibited in the bulletin board.

- Ask the students to reflect on what they would have done if they had been one of the characters in the tale, then to work in small groups to compare/justify their hypothetical actions. 
- Play a story treasure hunt. The plot of the story is simplified into a sequence of events that can be transcribed onto cards with short sections of the tale on each. The teacher hides the cards out of sequence throughout the school or classroom. Students use the

clues given in each card to find the next and, in that way, assemble the whole story in correct order.

- Ask the students to make a film version of the story. They have to cast the actors, decide on the director and perhaps make some modifications to adapt it for the big screen. They can work on this activity in groups, and then present the film to the rest of the class.

\section{The pedagogical innovation}

The primary aim of this pedagogical innovation was to investigate how the use of storytelling with a group of adult EFL learners could enhance their language skills and encourage their interest in literature. Thus, my innovation concentrated around the general question, "How can adult EFL learners benefit from the use of storytelling in the classroom?

\section{Participants}

A group of 15 students from my Express Yourself course 4 at the Centro Colombo Americano were the subjects in my project. There were 8 female students and 7 male students. Their age ranged from 17 to 35 years old. They were classified as pre-intermediate students at the institution and they had been studying English at the center for about four months.

\section{Setting}

The Centro Colombo Americano is a non-profit organization which is specialized in teaching English courses in all levels, from beginners to advanced students. The center offers comprehensive learning programs that encourage students to use strategies to learn more effectively and help them construct their own identity in the target language. The Colombo has also focused on promoting both the American and the Colombian culture, and in providing a meeting place for those captivated by the arts, films, literature, photography, painting, and any other cultural and artistic expressions. 


\section{Phases of the innovation}

Taking into account the story selection criteria mentioned before, I selected the penguin reader "The adventures of Tom Sawyer" by Mark Twain. In my opinion it is a story full of exciting events which is graded to their level. Besides, it contains colorful illustrations and comes with a cassette, which we could listen to in class.

My pedagogical innovation was implemented in a 6-week period. It included the last two weeks of my Express Yourself course 4 and all four weeks of course 5. The total number of sessions spent on the project was 14 .

In the table below, I will illustrate the stages of my project, the follow-up activities I carried out in each storytelling session, and the approximate time spent.

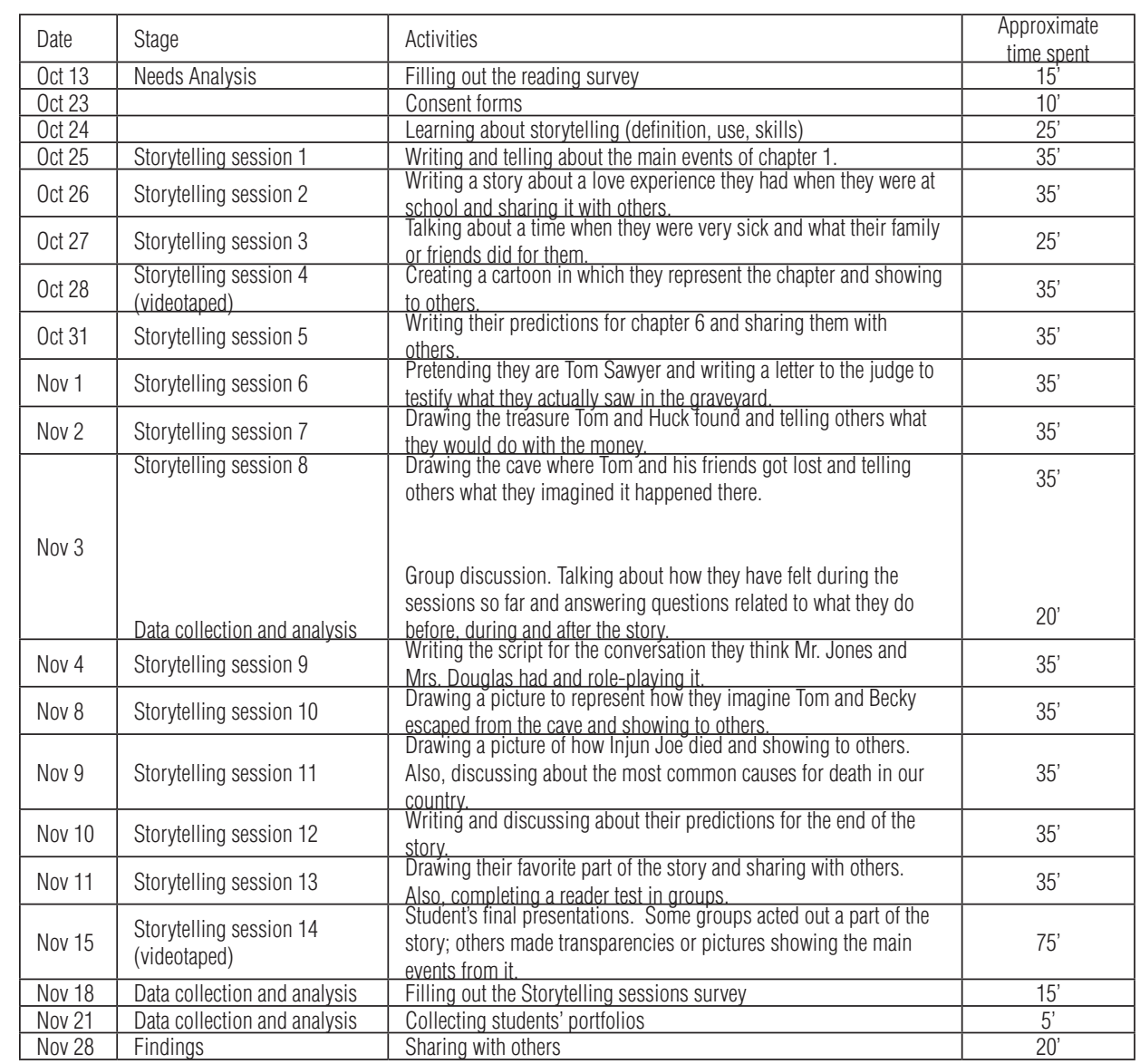


During all the storytelling sessions, the following steps were taken:

1. Listening to the story (using the audiotape) or reading it aloud in small groups. While the students were reading, I tried to jot down mispronunciations on a piece of paper or the board for later pronunciation practice.

2. Retelling the story in small groups. Sometimes, they took turns to retell the story and sometimes they chose one person to do it. I was very attentive to how the students retold the story as I wanted to see their storytelling performance skills. Students also received feedback from their peers and tried to make appropriate changes.

3. Sharing the follow-up activity (e.g. writing the letter, drawing a picture). From the small group discussions I gained valuable information for planning subsequent questions and activities

4. Providing time for reflection and assimilation. Both teacher and students had the opportunity to incorporate what they had learned from others, and clarifying their own points of view. I tried to use students' errors in comprehension or in written expression for further classroom learning activities.

\section{Data collection}

The data used to evaluate the results of my pedagogical innovation were collected from different sources. The first one was the reading questionnaire, which was used to find out students' perceptions on reading books in English and on the characteristics they considered storybooks should have (see Appendix B). The second one was the observations notes I took after some of the storytelling sessions, which helped me to evaluate students' language skills performance and attitudes towards the reading of the story (Appendix C). The third source was the students' portfolios, which served as an evidence of their work in class and at home. Through this source, I was also able to see the progress they made in terms of language skills throughout the project. The fourth one was the two video recorded sessions, which evidence students' enjoyment and engagement in the activities. The last one was the storytelling sessions survey I did to learn about students' comments on the project itself (Appendix D). In this questionnaire I asked them about their most and least favorite activities, as well as their feelings and roles when reading, retelling 
and listening to the story. The data were analyzed qualitatively and the characteristics or categories were derived both from the data and the existing research literature.

\section{Results}

Analysis of the study data, collected as class videotaped sessions, portfolios and researcher observations, along with questionnaires, showed that the 16 adult EFL students who signed consent forms (see Appendix A) were active participants in the process of responding to storytelling. A notable indicator was faithful attendance and participation in the sessions where no special grades were given. Thus, students constantly showed interest and enjoyment of both the storytelling class sessions and follow-up activities. An example of this is what was mentioned in the Storytelling sessions survey by participant \# 16, "Me sentí a gusto, y perdí la pereza de leer en inglés" ["I felt good, and I became interested in reading in English"]. Also, participant \# 13 said in regards to her role, "I was active, and I participate in all activities" and, she added, "Storytelling it's a good form to entertain and learn in the class".

However, there were some students who expressed their dislike towards the utilization of role-plays, one of the follow-up activities employed. For instance, participant \# 2 said, "La verdad no me gusta actuar, ya que soy un poco tímida y no tengo buena memoria y se me olvida el guión" ["The truth is that I don't like acting because I'm a little shy and I don't have a good memory and I forget the script"]. Also, participant \# 15 stated, "No me gusta la representación porque no soy muy buena actuando, prefiero escribir o hacer algún dibujo" [I don't like acting because I'm not good at it, I prefer to write or draw a picture"]. Some of this resistance can be attributed to the differences in learning styles students have and their personality.

Furthermore, students felt they had increased their oral output and understanding of grammar and vocabulary. Being able to respond articulately and knowledgeably to spontaneous questions in a free-talk environment lead to an increase in the ability to speak more freely on different topics. As participant \# 7 pointed out, "Es una buena actividad porque se adquiere vocabulary y habilidad para comunicarse verbalmente con otras personas" ["It's a good activity because we acquire vocabulary and we learn to communicate with others'] . Participant \# 15 added, "Nos permitió tener una lectura clara y 
aprender un poco más de vocabulario y gramática" [This activity allowed us to read better and learn more vocabulary and grammar"]. And participant \#2 concluded, "Fue bueno contar la historia porque aprendí a expresarme mejor en ingles. Además, tenia muchas ganas de narrar lo que había pasado y predecir lo que iba a pasar en el siguiente capitulo" [Telling the story was good because I learned to express myself in English better. Besides, I was always willing to narrate what had happened and predict what would happen in the next chapter of the story"].

Moreover, continuous interactivity was evident during all sessions. Through the discussions held by students and the role-plays students had a chance to exchange ideas, work cooperatively to construct the story events and establish interpersonal bonds.

Finally, students easily linked their own experiences to the story and appreciated the experience of story sharing to learn more about their classmates' points of view and thoughts. As indicated by participant \# 7, "Es bueno empezar a comprender lo que otras personas tienen por decir respecto a un tema en común" [It's good to understand what others have to say in regards to a specific topic"]. Also, as participant \# 11 expressed, "Me sentí bien escuchando a mis compañeros porque estábamos compartiendo ideas" [I felt good listening to my classmates because we were sharing ideas]. And, participant \#16 said, "Me gusto porque pude contar mis experiencias a partir de las de Tom. También escuchaba lo que le había pasado a los demás" [ "I liked the activity because I could talk about my own experiences based on Tom's experiences. Also, I could listen to what had happened to others"].

\section{Conclusions}

After implementing storytelling with my adult EFL students, I gained both knowledge and understanding on this teaching technique. Thus the main conclusions I came up with were these: first, storytelling teaches, informs, and provokes thought. Students are provided with various opportunities to express their feelings and opinions towards the issues raised in the text. Second, storytelling touches and reaches students as they are able to identify with the characters and situations, which provides insight and motives of behavior. Third, stories help develop language competence and listening skills, communication skills, and vocabulary. Fourth, storytelling can encourage and 
motivate students to search for more stories to read and tell as they increase their confidence to do it in the foreign language. And, lastly, telling stories stimulates students' imagination, brings laughter, understanding, and a sense of wonder and pleasure.

\section{Pedagogical implications}

My exploration of the use of storytelling with adult learners has added another piece to the puzzle on how to use literature in the EFL classroom. Since students demonstrated a lot of enjoyment, enhancement in their listening and oral skills and construction of philosophical concepts that related the stories to each other and to their backgrounds, this technique should start being implemented in other classes. Hence, more insights could be obtained from further exploration of its use with adults, in our particular social, cultural and educational setting.

Because I had a wonderful experience with this particular group of learners, I consider my colleagues should use storytelling with their students and see their own results. This might be a very innovative means to help students improve their language skills and begin developing their critical thinking in the target language.

\section{References}

Berman, M. (2006). The art of storytelling. Retrieved July 15, 2006, from www.developingteachers.com/articles_tchtraining/stpf_michael.htm

Berman, M. (2006). Ways of using stories in an ELT classroom. Retrieved July 15, 2006, from www.thestoryteller.org.uk/article.htm

Deacon, B. \& Murphey, T. (2001). Deep impact storytelling. English Teaching Forum, 39 (4), pp. 10-15

Hughes, K. \& Hughes, T. (1999). Oh, the tales you'll tell! English Teaching Forum, 37 (2), pp. 27-28.

Pedersen, E. M. (1995). Storytelling and the art of teaching. English Teaching Forum, 33 (1), pp. 2-5.

McWilliams, B. (1998). Effective Storytelling. A manual for beginners. Retrieved October 15, 2005, from http://www.eldrbarry.net/roos/eest.htm 
Morgan, M. \& Rinvolucri, M. (1983). Once upon a time: using stories in the language classroom. New York: Cambridge University Press.

Smallwood, B. (2003). Thematic literature and curriculum for English language learners in early childhood education. Retrieved October 30, 2005, http://ericdigests.org/20034/ece.html

Wright, A. (1995). Storytelling with children.Oxford: Oxford University Press.

THE AUTOR

Adriana M. Vecino holds a B.A. in Languages from Universidad Industrial de Santander and she is currently enrolled in the Masters Program in Applied Linguistics at Universidad Distrital. She is working at Centro Colombo Americano. Her focus on Language includes specific interests in storytelling, creative writing, and critical discourse analysis. E-mail: adriana_vecino@yahoo.com 


\title{
APPENDIX A CONSENT TO PARTICIPATE
}

\author{
Adriana Milena Vecino \\ Student of Master Program of Applied Linguistics to the Teaching of English as a Second \\ LanguageUniversidad Distrital Francisco José de Caldas
}

This pedagogical innovation aims to investigate the benefits of the use of storytelling with a group of adult EFL learners.

If you agree to participate in this project, you will be asked to the following things:

- Fill out two questionnaires. One in which you indicate your ideas and attitudes towards reading books in English. And, another which will serve as a means to evaluate your feelings, thoughts and reflections about the storytelling sessions.

- Develop the corresponding follow up activities after each chapter from the book is read. Some of the activities might be videotaped for analyzing your behaviors, attitudes and performance during the sessions.

- Keep all the written work in a portfolio in order to gain more valuable insights on your reading and writing processes.

- Participate in informal group discussions about the benefits and constraints of using storytelling in class.

If you agree to participate in this project, your data will be used by the researcher for the purpose of writing a pedagogical innovation proposal in her Master's, which is to be submitted in partial fulfillment of one of the seminars she is attending this present semester.

Your data will never be used for any other purposes. Your name will never be identified nor your privacy violated. If you have any questions about the project or how the data will be used, please feel free to ask the researcher any questions.

Certification of Consent:

I was informed and understand what the project is and how my data will be used. Thus, by signing below, I give my consent to participate in this project.

Signature of participant:

Date:

${ }_{\text {Day Month Year }}$ 


\section{APPENDIX B \\ Reading Survey}

Name:

Date:

1. What does reading mean to you?

2. What kind of books do you like to read?

3. Do you like reading storybooks in English? Why?

4. How often do you read storybooks in English?

5. Do you consider reading storybooks as a valuable strategy to learn and practice your English? Why?

6. What characteristics do you consider the storybook chosen to read in class should have? Circle Yes or No.

- Interesting topics

- Content appropriate to the student's language level 
- An introduction

- Clear illustrations that help understand the story

- Extensive activity material on vocabulary and reading Comprehension

- A glossary

yes no

- Any other?

If you have any additional comments, please write them here:

Thank you very much for your cooperation. 


\section{APPENDIX C}

\section{Storytelling sessions observation notes}

Teacher / observer: Adriana M. Vecino

Date:

Chapter:
Session No:

Time:

\begin{tabular}{|l|l|}
\hline Follow-up activities & Impressions, questions to ask \\
\hline 1. & \\
& \\
\hline 2. & \\
& \\
& \\
\hline
\end{tabular}




\section{APPENDIX D}

\section{Storytelling sessions Survey}

Name:

Date:

1. Did you enjoy having the storytelling sessions about Tom Sawyer's book? Why?

2. From all the follow up activities developed during the sessions, which one did you like best? Why?

3. Which activity did you like least? Why?

4. What other activities would you like to do in the next storytelling sessions? Why?

5. How would you describe your role during the storytelling sessions?

6. How did you feel while reading the story individually? 
7. How did you feel while telling the story to your classmates?

8. How did you feel while listening to your classmates' ideas and thoughts about the story?

If you have any additional comments, please write them here:

Thank you very much for your cooperation. 